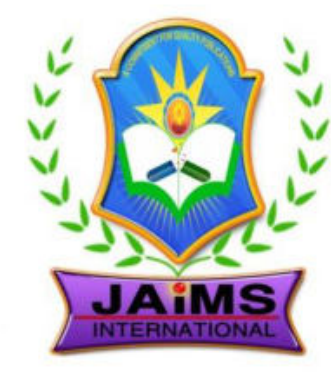

ISSN 2456-3110

Vol $5 \cdot$ Issue 1

Jan-Feb 2020

Journal of

Ayurveda and Integrated Medical Sciences

www.jaims.in

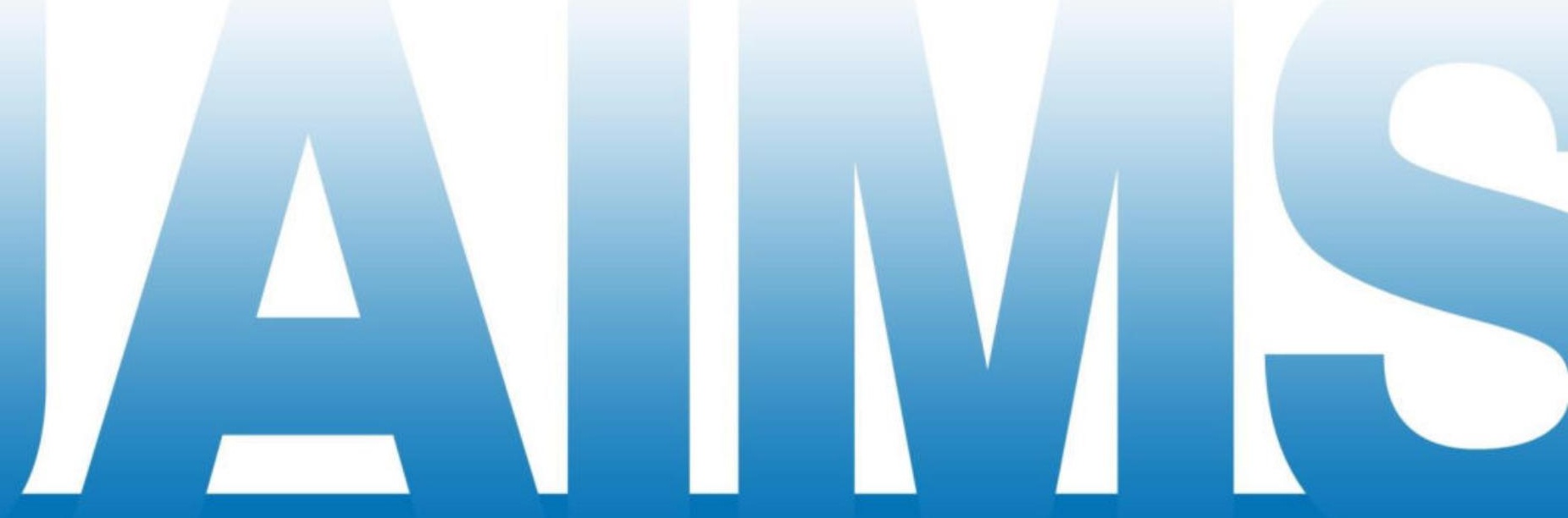

An International Journal for Researches in Ayurveda and Allied Sciences

\title{
Charaka
}




\title{
Ayurveda and Integrated Medical Sciences
}

\section{Comparative clnical study on the therapeutic effect of Saraswatharista and Jaladhara in Nidranasha w.s.r. to Insomnia}

\author{
Dr. Shiddanagouda K. B. ${ }^{1}$, Dr. K. B. Roy ${ }^{2}$ \\ ${ }^{1}$ Ph.D Scholar, Parul Institute of Ayurveda Vadodara Gujarat \& Assistant Professor, Dept. of Kayachikitsa, S. S. \\ Ayurvedic Medical College \& Hospital, Haveri, Karnataka, ${ }^{2}$ Professor, Dept. Of Kayachikitsa, Parul Institute of \\ Ayurveda, Vadodara, Gujarat, INDIA.
}

\section{A B S TR A C T}

\begin{abstract}
Nidra is considered as one among the Trayoupasthambha[1] which is very essential to lead happy and healthy life. In present era because of stressful lifestyle many people suffering from one or the other psychosomatic illnesses, among that insomnia is the most common health problem which affects the functions of central nervous system and even other systems. Around $9 \%$ of general population are suffering from insomnia, around $28 \%$ of people suffering from initiation and maintenance of sleep. At present the medical management of insomnia includes different variety of benzodiazepines' which causes various toxic effect and also drug dependency. For this one can find out the best remedies in Ayurvedic system of medicine, for the treatment of this disease. Saraswatharista ${ }^{[2]}$ is one of the best Shamana medicine with Bramhi Panchanga as main ingredient, having Rasayana effect as well as properties which can cure the diseases like Unmada, Mada, Apasmara as both Shareerika and Manasika Vyadhi are inter-related.[6] And Jaladhara is very safe, effective, readily available and cost effective without any side effect which mainly having Aaswasahara[4] and Nidrajanana action hence, present clinical trial is planned to compare the therapeutic effect of Saraswatharista and Jaladhara in Nidranasha with special reference to Insomnia is undertaken.
\end{abstract}

Key words: Nidra, Jaladhara, Saraswatharista, Benzodiazepines, Insomnia.

\section{INTRODUCTION}

Ayurveda is the holistic and time tested evidence based medicine which understands disease is mainly because of dushti of the either shareerika or manasika dosha. At present scenario of life because of stress most of the individuals are suffering from one or the

\section{Address for correspondence:}

Dr. Shiddanagouda K. B.

Ph.D Scholar, Parul Institute of Ayurveda Vadodara Gujarat \& Assistant Professor, Dept. of Kayachikitsa, S. S. Ayurvedic Medical College \& Hospital, Haveri, Karnataka, INDIA.

E-mail: siddanagouda88@gmail.com

Submission Date: 07/01/2020 Accepted Date: 18/02/2020

\begin{tabular}{|l|l|}
\hline & \\
\hline Quick Response Code & Access this article online \\
\hline & Website: www.jaims.in \\
\hline
\end{tabular}

other psychosomatic disorders. Ahara(Food) Nidra (Sleep) and Bramhacharya (Abstinence) are described to be the Trayopasthambas. Hence forth, Sleep is one of the essential thing to lead a healthy life. It has been rightly stated by Acharya Charaka that happiness \& misery, proper \& improper growth, good strength \& weakness, potency \& sterility, knowledge \& ignorance and life $\&$ death of an individual mainly depends on proper and improper sleep respectively.

Insomnia (inadequate quality and quantity of sleep) may be a symptom of stressful lifestyle, depressive illness, anxiety disorders, many psychiatric diseases or any other pathological conditions. Whatever may be the cause, it needs immediate attention. It is affecting nearly about $1 / 3^{\text {rd }}$ of population (especially youth) in western countries and the incidences are increasing day by day. If insomnia is left untreated, it may reduce mental capacity of an individual, hampers physiological functioning of body and ultimately it 
may drag the individual towards several severe psychosomatic aliments.

\section{OBJECTIVES OF THE STUDY}

1. To evaluate the therapeutic effect of Saraswatharista in Nidranasha.

2. To evaluate the therapeutic effect of Jaladhara in Nidranasha.

3. To compare the therapeutic effect of Saraswatharista and Jaladhara in Nidranasha.

\section{Materials ANd Methods}

\section{Inclusion Criteria}

- Patients of both sex between 16 to 60 years of age.

- Patients with signs and symptoms of Nidranasha-
- Jrimba (Yawing) Tandra (Drowsiness)
- Angamarda and angasada (Malaise)
- Shirashoola (Headache) Manodourbalya (Lack of concentration)
- Smritidourbalya ( Lack of memory) Indriya karmahani (Poor sensory perception)
- Ajirna \& Agnimandya (Indigestion) Malabadhata (Constipaion)
- Dhatu kshaya (Weight loss) Kanti kshaya (Loss of luster )

- Nidranasha patients with chronicity of 1 month to 10yrs.

\section{Exclusion Criteria}

- Patients below 16 yrs and after 60 yrs of age.

- Patients with major psychiatric illnesses like Schizophrenia, Bipolar mood disorder.

- Patients having chronic illness like IHD, COPD, malignancies.

- Patients with RTA.

\section{Diagnostic Criteria}

As per Nidranasha Laxana mentioned in classics
- Jrimba (Yawing), Tandra (Drowsiness)

- Angamarda and angasada (Malaise)

- Shirashoola (Headache), Manodourbalya (Lack of concentration)

- Smritidourbalya (Lack of memory), Indriya karmahani (Poor sensory perception)

- Ajirna \& Agnimandya (Indigestion), Malabadhata (Constipaion)

- Dhatu Kshaya (Weight loss), Kanti kshaya (Loss of luster)

\section{Design of the study}

Comparative clinical study with pre-test and post-test design.

Intervention

- Saraswatharista group (S -group): 20ml, twice a day, after food with warm water

- Jaladhara group (J - Group): The patients of this group were subjected to Jaladhara for 30 minutes daily in the Morning between 8:30 to 11:00 AM for 7days.

\section{Poorva Karma}

Dharapatra prepared from steel, whose mouth is wide and side are tapering gradually to a ventral point in the bottom. At the centre of this dharapatra a hole of little Finger size is made, at this point a brass cork was fixed with a provision of screw to Stop or start the Jaladhara. The capacity of the Patra was about 3 liters. Dharapatra was hanged on the hanger wire. So that it was about 4 finger ( 3 inches) just above the Patient's head.

The fresh tap water is used for Jaladhara at room temperature and it is collected to avoid wetting of the floor but not reused. The patient is asked to pass his natural urges before laying on Dhara table. The patients are allowed only to take tea, if they were addicted to it. The patient is asked to lay down on Dhara table on his back with his head resting on slightly elevated wooden platform made in the table. Than both the eyes covered with cotton piece. The 
patient's pulse, respiratory rate and blood pressure are recorded before starting the Jaladhara.

\section{Pradhana Karma}

The fresh tap water at room temperature is filled up about three fourth of its capacity in Dharapatra and poured in oscillating movement continuously on the forehead of the patient for 30 minutes. The fresh water is used to refill the Patra.

\section{Paschat Karma}

After Jaladhara, water is wiped with a napkin. Pulse, respiratory rate and blood pressure are again recorded. The patient is asked to sit in the room for some time before leaving the Dhara room.

Duration of study: 7 Days

Drug Ingredients

\begin{tabular}{|c|c|c|c|c|}
\hline SN & Drug & Botanical Source & $\begin{array}{l}\text { Part } \\
\text { Used }\end{array}$ & $\begin{array}{l}\text { Quantity } \\
\text { Used }\end{array}$ \\
\hline 1. & Brahmi & Bacopa monnieri & Plant & $6240 \mathrm{gm}$ \\
\hline 2. & Shatavari & $\begin{array}{l}\text { Asparagus } \\
\text { racemosus }\end{array}$ & Root & $1560 \mathrm{gm}$ \\
\hline 3. & Vidarika & Pueraria tuberose & Root & $1560 \mathrm{gm}$ \\
\hline 4. & Abhaya & Terminalia chebula & Pulp & $1560 \mathrm{gm}$ \\
\hline 5. & Ushira & Vetiveria zezanoides & Root & 1560gm \\
\hline 6. & Ardraka & Zingiber officinale & Rhizome & $1560 \mathrm{gm}$ \\
\hline 7. & Mishi & Foeniculum vulgare & Fruit & $1560 \mathrm{gm}$ \\
\hline 8. & Makshika & - & Honey & $3.12 \mathrm{~kg}$ \\
\hline 9. & Sita & $\begin{array}{l}\text { Saccharum } \\
\text { officinarum }\end{array}$ & & $7.8 \mathrm{~kg}$ \\
\hline 10. & Dhataki & Woodfordia fruticosa & Flower & 1560gm \\
\hline 11. & Renuka & Vitex negundo & Seed & $78 \mathrm{gm}$ \\
\hline 12. & Trivrt & $\begin{array}{l}\text { Operculina } \\
\text { turpethum }\end{array}$ & Root & 78gm \\
\hline 13. & Kana & Piper longum & Fruit & $78 \mathrm{gm}$ \\
\hline
\end{tabular}

\begin{tabular}{|l|l|l|l|l|}
\hline 14. & Devapushpa & $\begin{array}{l}\text { Syzygium } \\
\text { aromaticum }\end{array}$ & $\begin{array}{l}\text { Flower } \\
\text { bud }\end{array}$ & $78 \mathrm{gm}$ \\
\hline 15. & Vacha & Acorus calamus & Rhizome & $78 \mathrm{gm}$ \\
\hline 16. & Kushta & Saussurea lappa & Root & $78 \mathrm{gm}$ \\
\hline 17. & Vajigandha & Withania somnifera & Root & $78 \mathrm{gm}$ \\
\hline 18. & Vibheetaki & Terminalia bellirica & Pulp & $78 \mathrm{gm}$ \\
\hline 19. & Amruta & Tinospora cordifolia & Stem & $78 \mathrm{gm}$ \\
\hline 20. & Ela & $\begin{array}{l}\text { Elettaria } \\
\text { cardamomum }\end{array}$ & Seed & $78 \mathrm{gm}$ \\
\hline 21. & Vidanga & Embelia ribes & Fruit & $78 \mathrm{gm}$ \\
\hline 22. & Twak & $\begin{array}{l}\text { Cinnamomum } \\
\text { zeylanicum }\end{array}$ & $\begin{array}{l}\text { Stem } \\
\text { bark }\end{array}$ & $78 \mathrm{gm}$ \\
\hline
\end{tabular}

Assessment Criteria

\begin{tabular}{|l|l|l|l|l|l|}
\hline Questions & Never & Rarely & $\begin{array}{l}\text { Occasio } \\
\text { nally }\end{array}$ & $\begin{array}{l}\text { Most } \\
\text { nights/d } \\
\text { ays }\end{array}$ & $\begin{array}{l}\text { Alway } \\
\text { s }\end{array}$ \\
\hline $\begin{array}{l}\text { Do u have } \\
\text { trouble falling } \\
\text { asleep? }\end{array}$ & 1 & 2 & 3 & 4 & 5 \\
\hline $\begin{array}{l}\text { Do u have } \\
\text { trouble } \\
\text { staying sleep? }\end{array}$ & 1 & 2 & 3 & 4 & 5 \\
\hline $\begin{array}{l}\text { Do you wake } \\
\text { up un- } \\
\text { refreshed? }\end{array}$ & 1 & 2 & 3 & 4 & 5 \\
\hline $\begin{array}{l}\text { Do you take } \\
\text { anything to } \\
\text { help u sleep? }\end{array}$ & 1 & 2 & 3 & 4 & 5 \\
\hline $\begin{array}{l}\text { Do you use } \\
\text { alcohol to } \\
\text { help you } \\
\text { sleep? }\end{array}$ & 1 & 2 & 3 & 4 & 5 \\
\hline $\begin{array}{l}\text { Do you have } \\
\text { any medical } \\
\text { condition that } \\
\text { disrupts your } \\
\text { sleep? }\end{array}$ & 1 & 2 & 3 & 4 & 5 \\
\hline
\end{tabular}




\section{DisCUSSION}

Anidra or Nidranasha is enumerated as one among the Vataja nanatamaja vikara. It is also included as one of the symptoms in Vata \& Pitta Dosha Vriddhi Lakshanas and certain diseases. Kaphadosha, Tamas, Hridaya and Samjnavaha srotas are responsible for induction of sleep. During the explanation of Nidra Utpatti classical texts explained that both Shareerika and manasika Dosha palys an important role. when manas become klanta, indriya are unable to perform their normal function. In case of Nidranasha the available modern medicines are having various adverse effect and even drug dependency for that Ayurvedic system of medicine is having very safe and effective remedies. Saraswatharista is the very common drug having best medhya drug that is Bramhi panchanga. And even it acts as best rasayana and shamana medicine having chittasantosha and nidrajanana action.

\section{CONCLUSION}

To conclude on the basis of various clinical trials it is proved that Saraswatharista is considered best drug of choice in Nidranasha. And it is very simple, common medicine with Bramhi panchanga as main ingredients having tikta rasa, ushna veerya and medhya property. Nidranasha is one among the vataja natmaja vikara for vata shamana, nidrajanana and aaswasahara action saraswatharista and jaladhara are very safe,cost effective and easily available medicines.

\section{REFERENCES}

1. Agnivesha, Caraka samhita Ayurveda deepika by cakrapanidatta edited by vaidya jadavaji trikamji Acharya, chaukhambha prakashan, Varanasi, edition2009, sutrasthana, $10^{\text {th }}$ chapter, verse no.35, Page no.74,pp 738

2. Bhishajya Ratnavalli by Kaviraj shri govind das sen edited by Prof. Siddhinandan Mishra, chaukhambha surbharati prakashan, Varanasi, edition-2011, rasayanarogadhikara, chapter no. 73 , verse 148-171, page no.1120-1121, pp 1196
3. Agnivesha, Caraka samhita Ayurveda deepika by cakrapanidatta edited by vaidya jadavaji trikamji Acharya, chaukhambha prakashan, Varanasi, edition2009 , sutrasthana, $10^{\text {th }}$ chapter, verse no.35, Page no.74, pp 738

4. Agnivesha, Caraka samhita ayurveda deepika by cakrapanidatta edited by vaidya jadavaji trikamji Acharya, chaukhambha prakashan, Varanasi, edition2009 , sutrasthana, chapter no. 21 , verse 36 , page no.118, pp 738

5. Agnivesha, Caraka samhita ayurveda deepika by cakrapanidatta edited by vaidya jadavaji trikamji Acharya, chaukhambha prakashan, Varanasi, edition2009, sutrasthana, chapter no.20, verse 11,page no.113, pp 738

6. A clinical study on the effect of Takradhara and Mamshadi kashaya in Nidranasha by Dr. Raviprasad. H., SDM College Of Ayurveda Kuthpady, Udupi-20142015,pp 103

7. A clinical study to evaluate the therapeutic effect of Saraswatharista in Vataja shirashoola dusti (Tension headache) by Dr.Dhaneswari.U.A, SDM College of Ayurveda Kuthpady, Udupi-2014-2015, pp 109

8. Harrison's principles of internal medicine, $16^{\text {th }}$ edition, page no. 1549, pp 2754

9. Agnivesha, Caraka samhita ayurveda deepika by cakrapanidatta edited by vaidyajadavaji trikamji Acharya, chaukhambha prakashan, Varanasi, edition2009, Nidanasthana, chapter no.1, verse 5, page no.194, pp 738

10. Agnivesha, Caraka samhita ayurveda deepika by cakrapanidatta edited by vaidyajadavaji trikamji Acharya, chaukhambha prakashan, Varanasi, edition2009 , vimanasthana, chapter no.6, verse 8 , page no. $254, p p 738$

11. Sushruta samhita nibandha sangraha by dhalhana edited by vaidya jadavaji trikamji Acharya, chaukhambha sanskrit sansthan, Varanasi, edition 2012, sutrasthana, chapter no.1, verse no.24 (3), page no.6pp 824

12. Rationale of ayurvedic psychiatry by.Dr.A.R.V.Murthy, chaukhambha orientalia, Varanasi, edition 2009, page no.290 to 316 pp 531 
How to cite this article: Dr. Shiddanagouda K. B., Dr. K. B. Roy. Comparative clnical study on the therapeutic effect of Saraswatharista and Jaladhara in Nidranasha w.s.r. to Insomnia. J Ayurveda Integr Med Sci 2020;1:26-30.

http://dx.doi.org/10.21760/jaims.5.1.6

Source of Support: Nil, Conflict of Interest: None declared.

Copyright (C) 2020 The Author(s); Published by Maharshi Charaka Ayurveda Organization, Vijayapur (Regd). This is an open-access article distributed under the terms of the Creative Commons Attribution License (http://creativecommons.org/licenses/by/4.0), which permits unrestricted use, distribution, and reproduction in any medium, provided the original work is properly cited. 